\title{
GROWTH AND REPRODUCTION DATA OF PLESIONIKA NARVAL (DECAPODA, CARIDEA, PANDALIDAE) OFF THE ISLAND OF USTICA (SOUTHERN TYRRHENIAN SEA)
}

\author{
BY \\ M. ARCULEO ${ }^{1,2}$ ) and S. LO BRUTTO ${ }^{1}$ ) \\ 1) Dipartimento di Biologia Ambientale e Biodiversità,Via Archirafi, 18, I-90123 Palermo, Italy
}

\begin{abstract}
We here report some data on the biology and population structure of Plesionika narval (Fabricius, 1787) captured along the coast of the island of Ustica in the southern Tyrrhenian Sea. Specimens were collected monthly from January to October 2000 using commercial traps at depths ranging from 15 to 100 metres. The carapace length (CL) of females ranged between 7.0 and $26.0 \mathrm{~mm}$, and between 7.0 and $17.0 \mathrm{~mm}$ for males. Three modes were identified in the cumulative frequency distribution for females but only two for males. In females, the third modal value was observed only at the deeper sample sites. The Von Bertalanffy growth parameters and performance index $\varphi$ were $\mathrm{K}=0.65 \mathrm{y}^{-1}, \mathrm{CL} \infty=27.4 \mathrm{~mm} \mathrm{CL}$ and $\varphi=2.62$ for females, and $\mathrm{K}=0.71 \mathrm{y}^{-1}$, $\mathrm{CL} \infty=17.8 \mathrm{~mm} \mathrm{CL}$ and $\varphi=2.28$ for males. Ovigerous females were found during the entire period of the investigation, indicating that this species spawns all year round. We compared our results with other data recorded in the literature.
\end{abstract}

\section{RIASSUNTO}

Si riportano alcuni dati sulla biologia e la struttura di popolazione di Plesionika narval (Fabricius, 1787) catturata lungo le coste dell'Isola di Ustica. Gli individui sono stati pescati a differenti profondità utilizzando nasse commerciali durante il periodo compreso tra Gennaio e Ottobre 2000. La distribuzione di frequenza di lunghezza carapace (LC) nelle femmine è risultata compresa tra 7,0 e $26,0 \mathrm{~mm}$, mentre nei maschi tra 7,0 e $17,0 \mathrm{~mm}$. Sono stati identificati tre valori modali nelle femmine, mentre solo due nei maschi. Il terzo valore modale nelle femmine è stato osservato solo nei campioni più profondi. I parametri di crescita e l'indice di performance stimati utilizzando l'equazione di Von Bertalanffy hanno dato i seguenti valori $\mathrm{K}=0,65 \mathrm{y}^{-1}, \mathrm{CL} \infty=27,4 \mathrm{~mm}$ $\mathrm{CL}$ e $\varphi=2,62$ per le femmine, e $\mathrm{K}=0,71 \mathrm{y}^{-1}, \mathrm{CL} \infty=17,8 \mathrm{~mm}$ di CL and $\varphi=2,28$ per i maschi. Per quanto riguarda l'aspetto riproduttivo, femmine ovigere sono state trovate durante tutto il periodo di indagine indicando che questa specie si riproduce più volte durante l'anno. Le nostre informazioni, nuove per il Mar Tirreno, sono state confrontate con quelle presenti in altre aree del Mediterraneo e dell'Atlantico.

2) e-mail: marculeo@unipa.it

(C) Koninklijke Brill NV, Leiden, 2011 


\section{INTRODUCTION}

Plesionika narval (Fabricius, 1787) is a temperate pandalid with a wide geographical distribution in the eastern central Atlantic, the western Indian Ocean, and the western-central Pacific (Gonzales et al., 1997; Landeira et al., 2009). In the Mediterranean Sea, it mainly occurs in the western area and rarely appears in the eastern part (Fisher et al., 1987), even though Cristodoulou et al. (2009) recently found this species along the coast of Cyprus. Its bathymetric distribution ranges from the first metres of the water column to $-900 \mathrm{~m}$ (Holthuis, 1980; ThessalouLegaki et al., 1989). The species also lives in shallow water inside submarine caves or rocky cavities, whereas it can be found on sand or muddy substrates at greater depths. In the Tyrrhenian Sea, it is usually caught with traps and less frequently by bottom trawls (Anonymous, 1988). In general, it is not common on the Italian markets, whereas in the Canary Islands, it represents an important artisanal fishery resource as there it forms sizeable concentrations and is easily caught (Gonzales et al., 1997).

On the island of Ustica, $P$. narval has an important economic role for local fishermen and hence for the economy of the island. In fact, it is considered a very attractive species for tourists during the summer period for two main reasons:

(i) local restaurants serve this species raw and marinated in oil and lemon, and (ii) divers visit attractive natural submarine caves on the island called "caves of shrimps" where this species is abundant.

To date, and considering its general economic importance, few studies have been carried out on the population structure and biology of this crustacean. The only data on the species inside the Mediterranean Sea are those reported by Ferrero (1969) in the Tuscan Archipelago, Thessalou-Legaki $(1989,1992)$ and Thessalou-Legaki et al. (1989) on the Island of Rhodes (Greece), while outside of the Mediterranean Sea, we have data by Figueira (1960) from the Azores islands, Biscoito (1993) from Madeira, and by Figueira (1960) and Gonzalez et al. (1997) from the Canary Islands. Only recently, Landeira et al. (2009) studied the larval stages of this species and compared them with those of other Pandalidae.

The aim of the present study was to report new data of this species on its biology and population structure in the southern Tyrrhenian Sea, and to compare these results with other data recorded in the literature.

\section{MATERIAL AND METHODS}

Specimens of Plesionika narval were collected using commercial traps at depths ranging from 15 to $100 \mathrm{~m}$ at eight sample sites around the island of Ustica (fig. 1) with the following different habitats noted: stations 1 to 6 , rocky bottom with 


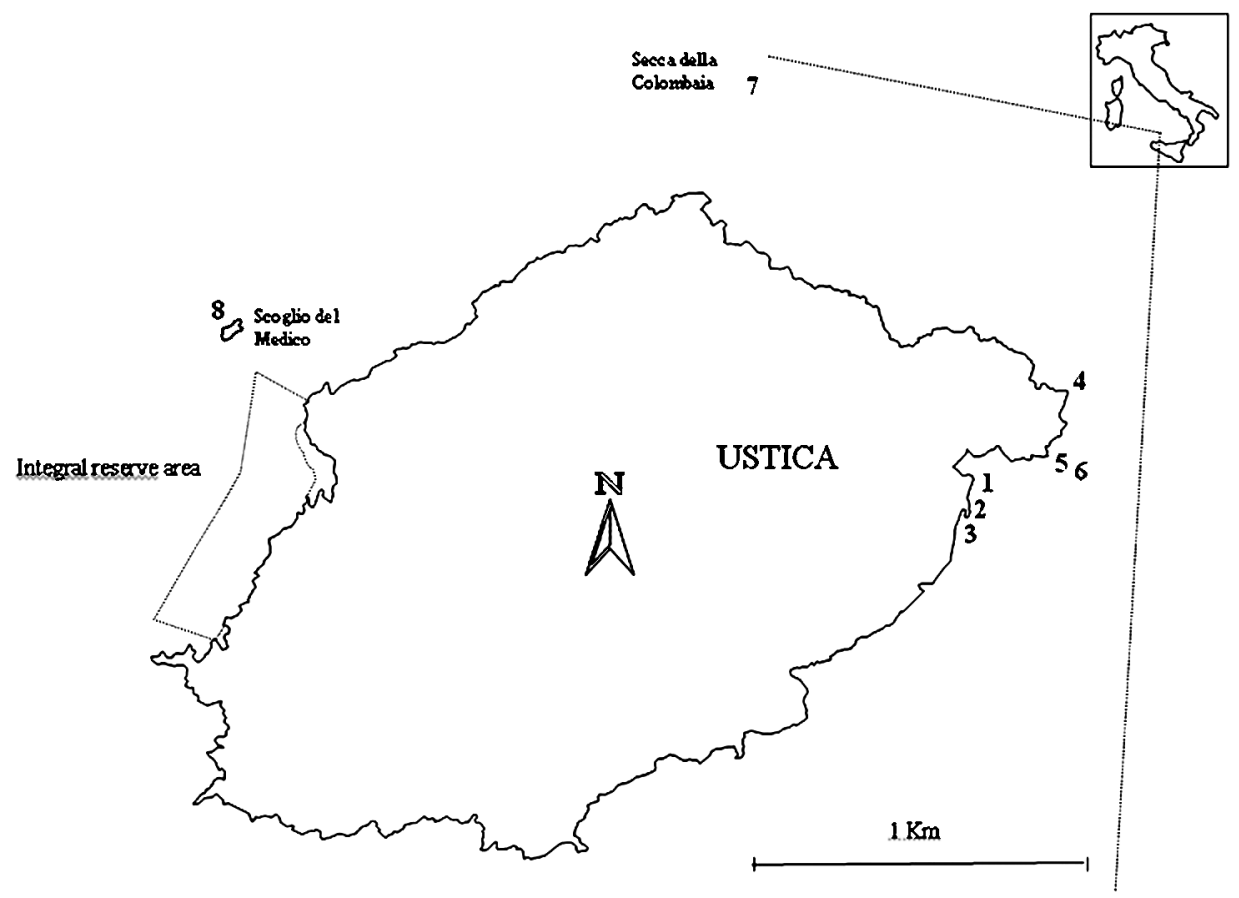

Fig. 1. Map of the study area showing the sample sites.

submarine caves; stations 7 and 8, rocky or muddy bottom. Sampling was carried out monthly for one year from January to October 2000 at sample sites 1 to 6 in a depth range of 15 to 80 metres. At sample sites 7 and 8 , collections were made only in April and October at 80 to 100 metres deep. No samples were obtained in November and December, as a consequence of bad weather conditions. The choice of sample sites and depths was influenced by the advice of local fishermen, and fishing was performed at night, from sunset to sunrise, over a period of approximately 12 hours.

All specimens were measured to the nearest $0.1 \mathrm{~mm}$ by Vernier callipers from the rear of the eye socket to the rear edge of the carapace (CL) and weighed to the nearest $0.01 \mathrm{~g}$; ovigerous females were weighed after removal of the eggs. Following Thessalou-Legaki (1989), the sex of each individual was determined by examining the endopods of the first two pleopods, and females were also separated with respect to their ovigerous or non-ovigerous condition. The stage of egg maturation was recorded according to the following three-stage scale (Ceccaldi, 1968; Thessalou-Legaki, 1992; Chilari et al., 2005): stage $a$, blue eggs with embryos without eye pigmentation; stage $b$, light blue eggs with slight eye pigmentation of embryos; and stage $c$ light brown eggs with clearly visible eyes and well-developed embryos. 
Size frequency distributions of females and males, in 1-mm intervals, were plotted for the whole period. Length-frequency distributions of each sex were separated by model progression analysis (Bhattacharya method) using FISAT version 2 (Gayanilo et al., 2005). A cohort was assumed valid if the separation index was greater than 2. Average shrimp size along the depth gradient investigated was compared by ANOVA, in particular we considered both sexes and the two depth ranges of the sample sites: 15-80 m (sites 1-6) and 80-100 m (sites 7-8).

The relationship between carapace length and weight was calculated for each sex for the entire period studied using the equation: $\mathrm{W}=a \times \mathrm{CL}^{b}$ (W in $\mathrm{g}, \mathrm{CL}$ in mm and $a$ and $b$ are parameters that need to be estimated).

The relationship between carapace length and age was modelled using the Von Bertalanffy growth function. The estimation of growth parameters was conducted using the ELEFAN I routine incorporated in the FISAT II software (Gayanilo et al., 2005). The growth performance index $\varphi$ (Pauly \& Munro, 1984) was estimated by the equation $\varphi=\log _{10} \mathrm{k}+2 \log _{10} \mathrm{CL} \infty$.

\section{RESULTS}

A total of 5768 of Plesionika narval (4744 females and 1024 males) were caught between January and October 2000 and all individuals were measured, weighed, and their sexes determined.

The length-frequency distribution for the whole sample showed that females ranged between 7 and $26 \mathrm{~mm}$ CL (mean $14.3 \pm 1.9 \mathrm{SD}$ ), while males ranged between 7 and $17 \mathrm{~mm} \mathrm{CL}$ (mean $12.4 \pm 1.7 \mathrm{SD}$ ) (fig. 2). In particular at the

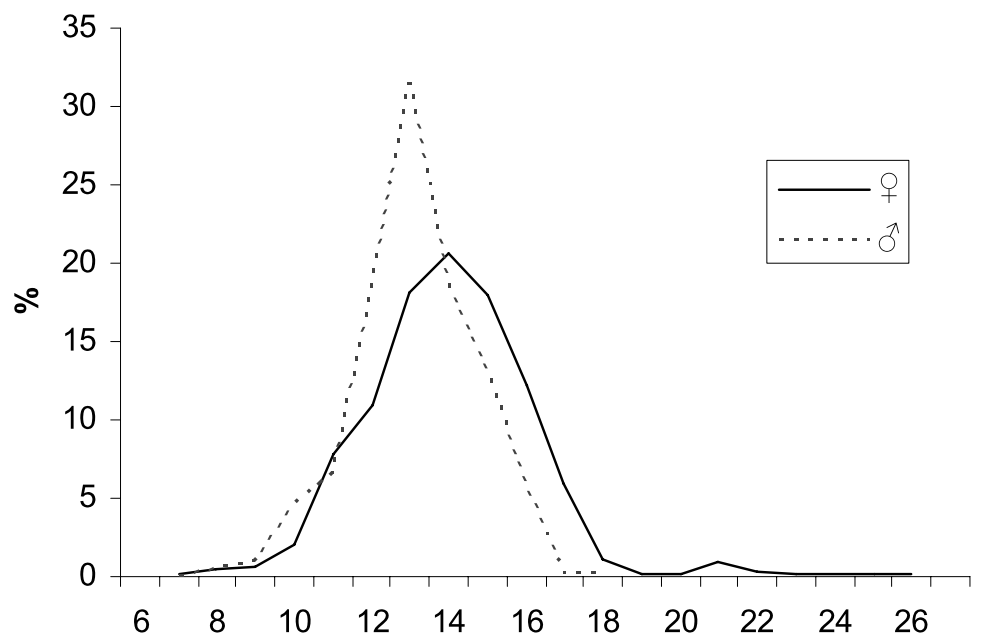

Fig. 2. Length-frequency distribution (CL mm) of males and females of Plesionika narval (Fabricius, 1787). 


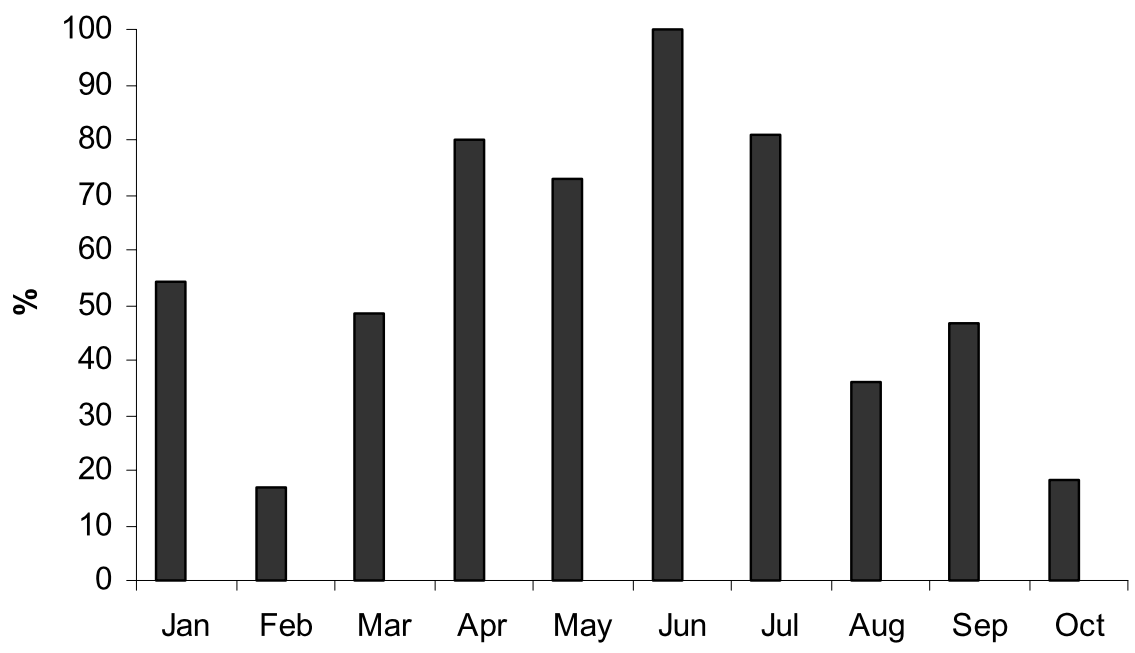

Fig. 3. Monthly frequency of ovigerous Plesionika narval (Fabricius, 1787).

depth range of $15-80 \mathrm{~m}$ the average $\mathrm{CL}$ of females was $13 \mathrm{~mm}( \pm 2.3 \mathrm{SD})$, with $12.0 \mathrm{~mm}( \pm 2.1 \mathrm{SD})$ for the males. Deeper samples $(80-100 \mathrm{~m})$ of ovigerous and non-ovigerous females showed an average CL of $15.6 \mathrm{~mm}( \pm 2.1 \mathrm{SD})$ and 17.8 ( $\pm 1.3 \mathrm{SD})$, respectively, while $12.5 \mathrm{CL} \mathrm{mm}( \pm 1.9 \mathrm{SD})$ was recorded in males. The average $\mathrm{CL}$ of males in the depth range considered $(15-100 \mathrm{~m}) \mathrm{did}$ not show significant differences $(p>0.05$, d.f. $=7)$, whereas this value increased significantly with depth only in non-ovigerous females $(p<0.05$, d.f. $=7)$.

Using Bhattacharya's method, three modes were identified in the cumulative frequency distribution of females: $8.87,13.85$, and $22.96 \mathrm{~mm} \mathrm{CL}$, whereas only two, 8.84 and $12.26 \mathrm{~mm} \mathrm{CL}$, were observed for males. In females, the third modal value $(22.96 \mathrm{~mm})$ was observed only at the two deep stations (7 and 8).

The Von Bertallanffy growth parameters and performance index $\varphi$ were $\mathrm{K}=$ 0.65 year $^{-1}, \mathrm{CL} \infty=27.4 \mathrm{~mm} \mathrm{CL}$, and $\varphi=2.62$ for females, and $\mathrm{K}=$ 0.71 year $^{-1}, \mathrm{CL} \infty=17.8 \mathrm{~mm} \mathrm{CL}$, and $\varphi=2.28$ for males.

The carapace length-weight relationship suggested that weight increased with negative allometry. In fact, the values of the allometric coefficient $b$ varied between 2.39 and 2.65 , more specifically 2.6 in ovigerous and 2.39 in non-ovigerous females, and 2.51 in males. Correlation coefficients ranging from 0.85 to 0.93 indicated a strong relationship between $\mathrm{CL}$ and wet weight.

Ovigerous females were found during the entire period of the investigation, implying that this species spawns all year round (fig. 3). In particular, the highest percentage of ovigerous females was recorded in June (100\%) whereas the lowest values were registered in February $(17.1 \%)$ and October (18.2\%). The three different egg-maturation stages are shown in fig. 4 . Ovigerous females with blue 


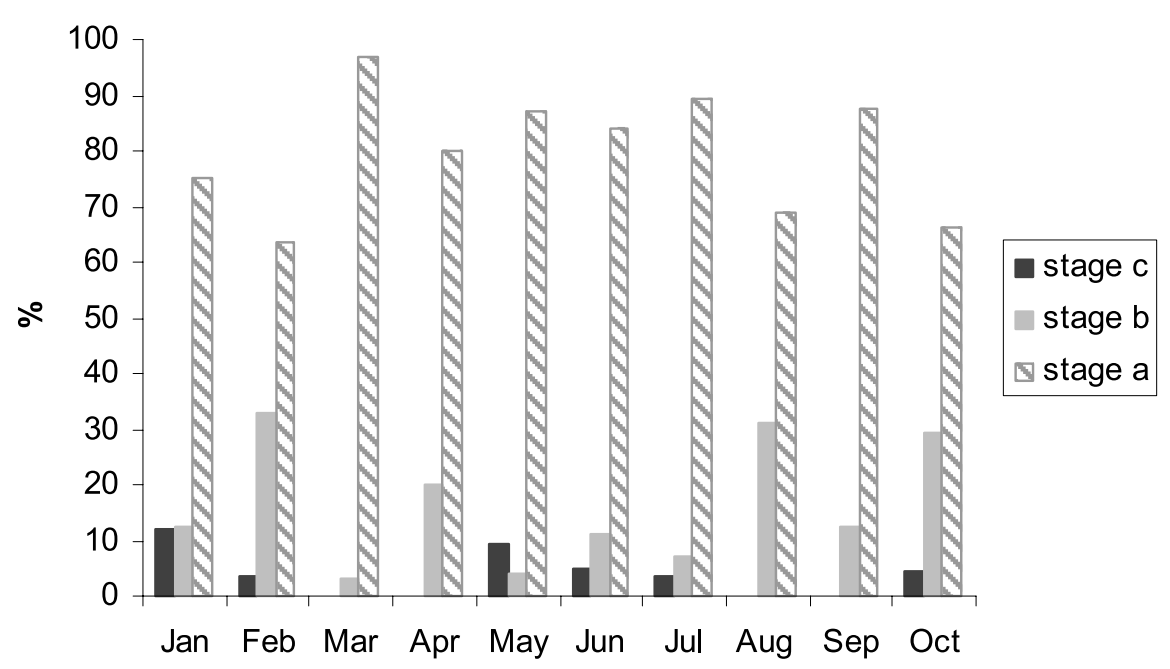

Fig. 4. Monthly frequency of the egg-maturation stages of Plesionika narval (Fabricius, 1787).

and light blue eggs were present during the entire period investigated at different frequencies: blue eggs displayed a higher monthly frequency than light blue eggs. Stage $c$ (light brown eggs) was not observed in every month.

The smallest female bearing eggs of the first two stages had a carapace length of $7 \mathrm{~mm}$, whereas the smallest one with eggs at stage $c$ measured $10 \mathrm{~mm} \mathrm{CL}$.

\section{DISCUSSION}

The analysis of the size frequency distributions of Plesionika narval showed a clear size predominance of females over males. Moreover, female size increased with increasing depth $(p<0.05$, d.f. $=7)$; in fact, the maximum CL $(26 \mathrm{~mm})$ of females was found only at depths between 80 and 100 metres (sites 7 and 8) and contributed to the identification of the third age group (modal class value of $22.96 \mathrm{~mm}$ ). This result is in agreement with those reported by Thessalou-Legaki et al. (1989) and Gonzalez et al. (1997) for the same species, Frechette \& Parson (1983) for Pandalus borealis Krøyer, 1838, and Chilari et al. (2005) for Plesionika martia (A. Milne-Edwards, 1883), who found a strong relationship between size and depth. According to Cartes (1993), the size-related depth segregation in some Pandalidae seems to be linked to a decrease in competition for space and food resources among the size classes. Indeed, dietary diversity is associated with depth. Moreover, it is well known that the euphotic zone, or the stratum just below that, gets a rich supply of food in the form of phytoplankton and suspended matter for juvenile and larval phases (Omori, 1974). This trend in size-depth relationship was also highlighted for Penaeidae by Froglia (1982) and Ardizzone et al. (1990), 
and for Aristeidae by Mura \& Cau (1989). Conversely, our data did not show a significant relationship between depth and carapace length in males $(p>0.05$, d.f. $=7$ ), showing a general maintenance of size with increasing water depth. This is in agreement with the results obtained by Frechette \& Parson (1983), ThessalouLegaki et al. (1989), and Gonzalez et al. (1997).

The length frequency analysis (Bhattacharya's method) showed three possible age classes in females with the third age group present only at the deep sample sites ( 80 to $100 \mathrm{~m}$ ), an observation in accordance with the data reported by ThessalouLegaki et al. (1989) from Rhodes Island, where the main age group was represented by the second (97\%) mode. In males, we identified two modes with the second age group more representative (85\%) and without any depth-related differences. Our data on the presence of three (female) and two (male) modal classes are similar to those obtained by Thessalou-Legaki et al. (1989), but are different from those of Gonzalez et al. (1997) who found six modes in both sexes. It is not easy to speculate about this discrepancy with the data of Gonzalez et al. (1997), who worked with a similar individual size range ( 7 to $30 \mathrm{~mm}$ in CL).

The Von Bertalanffy growth parameters and performance index $\varphi$ appeared similar to those of the other species of Pandalidae (Gonzales et al., 1997, and references therein) and confirmed a general slightly higher growth rate in females $(\varphi=2.62)$ than in males $(\varphi=2.28)$.

The length-weight relationship showed negative allometric growth in males, and ovigerous and non-ovigerous females, and reflected the decreasing growth rate in relation to CL. These data are in agreement with those obtained for other Pandalidae (Maiorano et al., 2002, and references therein) and for the same species in the Canary Islands by Gonzalez et al. (1997). However, it is in contrast to those reported by Thessalou-Legaki et al. (1989) in the islands of Greece, where they found isometric growth. This difference is not easy to explain and could probably be linked to the origin of the sample (depth and water temperature).

Considering the spawning period, the highest percentage of ovigerous females occurred mainly in spring (April, 80\%) and summer (June, 100\%), even though ovigerous females were present during the whole year. This is consistent with the data of Gonzalez et al. (1997) based on the Canary Islands, and Thessalou-Legaki (1992) along the Greek coast. If we consider the third egg stage, we identified the summer season as the most representative of this stage, even if it was present in the other months.

In conclusion, the data on the biology of Plesionika narval around Ustica Island seem to be in accordance with earlier data collected in other parts of the Mediterranea Sea (Thessalou-Legaki, 1989, 1992; Thessalou-Legaki et al., 1989) and from the Atlantic Ocean (Gonzales et al., 1997) although, concerning the population structure, our data fit better those reported for the Mediterranean 
Sea than those from the Atlantic. Of course, more data on local oceanographic conditions and more adequate experimental design of sampling are needed to better explain the population structure of this economically important species. Moreover, as reported above, depth appears to be a fundamental factor to take into account, due to the qualitative and quantitative differences in food found along the depth range. This knowledge might be important for future management strategies that should be considered in order to maintain adequate fishing pressure.

\section{ACKNOWLEDGEMENTS}

This research was supported by C.I.R.I.T.A., Municipality of Ustica, and Fondi di Ateneo (ex 60\%).

\section{REFERENCES}

ANONymous, 1988. Valutazione delle risorse demersali. Atti seminari pesca e aquacoltura. Ministero Marina Mercantile Roma, 3: 1-1797.

Ardizzone, G. D., M. F. Gravina, A. Belluscio \& P. Schintu, 1990. Depth-size distribution pattern of Parapenaeus longirostris (Lucas, 1846) (Decapoda) in the central mediterranean sea. Journ. Crust. Biol., 10: 139-147.

Biscoito, M. J., 1993. An account of the shrimps of the family Pandalidae (Crustacea, Decapoda, Caridae) in Madeiran waters. Courier Forsch.-Inst. Senckenberg, 159: 321-325.

CARTES, J. E., 1993. Diets of deep-water pandalid shrimps on the western Mediterranean slope. Mar. Ecol. Progr. Ser., 96: 49-61.

CeCCAlDi, H. J., 1968. Evolution des oeufs et cycle de reproduction chez Plesionika edwardsi (Brandt). Rec. Trav. Sta. mar. Endoume, 60: 403-312.

Chilari, A., M. Thessalou-Legaki \& G. Petrakis, 2005. Population structure and reproduction of the deep-water shrimp Plesionika martia (Decapoda: Pandalidae) from the eastern Ionian Sea. Journ. Crust. Biol., 25: 233-241.

Christodoulou, M., T. Tzomos, N. Chartosia \& K. Miltiadis-Spyridon, 2009. Decapod crustaceans new to the fauna of Cyprus. Mar. Biodiv. Records, 2: 1-4.

Ferrero, L., 1969. Parapandalus narval (Fabricius) in una grotta dell'Isola di Giannutri Arcipelago Toscano. Boll. Pesca Pisci. Idrobiol., 20 (3): 163-168.

FigueIRA, A. J. G., 1960. Madeiran decapod crustaceans in the collection of the museum Municipal do Funchal. I. On some interesting deep-sea prawns of the families Pasiphaeidae, Oplophoridae and Pandalidae. Bol. Mus. mun. Funchal, 26: 22-51.

FisheR, W., M. L. BAUCHOT \& M. SCHNEIDER, 1987. Fishes FAO identification, 1: 1-250. (FAO, Rome).

FrÈchette, J. \& D. J. PeArson, 1983. Report of shrimp ageing workshop. NATO Scientific Council Studies, 6: 79-100.

Froglia, C., 1982. Contribution to the knowledge of the biology of Parapenaeus longirostris (Lucas) (Decapoda, Penaeoidea). Quad. Lab. Tecn. Pesca, 3: 163-168.

Gayanilo, F. C., J. R. P. Sparre \& D. PAUly, 2005. The FAO-ICLARM stock assessment tools II (FiSAT II) reference manual: 1-168. (F.A.O. Computerized Information Series, Fisheries, 8, Revised version). (FAO, Rome). 
Gonzales, J. A., V. M. Tuset, I. J. LozAno \& J. I. SAntanA, 1997. Biology of Plesionika narval (Crustacea, Decapoda, Pandalidae) around the Canary Islands (eastern central Atlantic). Estuar. coast. Shelf Sci., 44: 339-350.

HolthuIs, L. B., 1980. FAO species catalogue, 1. Shrimps and prawns of the world. An annotated catalogue of species of interest to fisheries. FAO Fisheries Synopsis, 125: 1-261. (FAO, Rome).

LANDEIRA, J. M., F. LoZANO-SOldevilla \& J. I. GonZAlES-Cordillo, 2009. Description of the first five stages of Plesionika narval (Fabricius, 1787) (Crustacea, Decapoda, Pandalidae) obtained under laboratory conditions. Zootaxa, 2206: 45-61.

Maiorano, P., G. D’Onghia, F. CAPEZzUTO \& L. Sion, 2002. Life-histrory traits of Plesionika martia (Decapoda: Caridea) from the eastern-central Mediterranean Sea. Mar. Biol., Berlin, 141: 527-539.

Mura, M. \& A. CAU, 1989. Sul dimorfismo sessuale e sex-ratio in Aristeus antennatus (Risso, 1816). Oebalia, 15: 811-814.

OMORI, M., 1974. The biology of pelagic shrimps in the ocean. Adv. mar. Biol., 12: 233-324.

TheSSALOU-LEGAKI, M., 1989. Allometric growth of male secondary sexual characters and dioecy in Parapandalus narval (Decapoda: Pandalidae). Journ. Crust. Biol., 9: 595-600.

— _ 1992. Reproductive variability of Parapandalus narval (Crustacea: Decapoda) along a depth gradient. Estuar. coast. Shelf Sci., 35: 593-603.

Thessalou-Legaki, M., A. Frantzis, C. Nassiokas \& S. Hatzinikolaou, 1989. Depth zonation in a Parapandalus narval (Crustacea, Decapoda, Pandalidae) population from Rhodos Island, Greece. Estuar. coast. Shelf Sci., 29: 273-284.

First received 5 May 2011.

Final version accepted 4 August 2011. 